\title{
Progress of the components and biological activities of Morinda officinalis How
}

\author{
Olagoke Z Olatunde ${ }^{1}$, Yang Yang, ${ }^{1,2}$, Jianping Yong ${ }^{3 *}$ and Canzhong Lu ${ }^{1,3 *}$ \\ ${ }^{1}$ Fujian Institute of Research on the Structure of Matter, Haixi Institute, Chinese Academy of Sciences, Fuzhou, China \\ ${ }^{2}$ Shanghai Tech University, Shanghai, China \\ ${ }^{3}$ Xiamen Institute of Rare-earth Materials, Haixi Institute, Chinese Academy of Sciences, Xiamen, China
}

\begin{abstract}
The Morinda officinalis How is “one of the top four south authentic traditional Chinese medicines”, widely distributed in South District of China, such as Fujian, Guangdong, Guangxi, Hainan, etc. Its roots are widely used for the treatment of sexual impotence, spermatorrhea, irregular menstruation, and female infertility in clinical. Many kinds of compounds (iridoid glycosides, anthraquinones, saccharides, organic acids, volatile oils and homogeneous polysaccharides) have been isolated from its roots and the relevant biological activities (pain-killing, antioxidant, antibacterial, anticancer, anti-inflammatory, anti-tubercular and cardiovascular action) were also studied. This review briefly describes the botanical description, plant taxonomy, history of medicinal development and the progress of the chemical components and biological activities of $M$. officinalis to provide a reference for the researchers.
\end{abstract}

\section{Introduction}

Over the years, plant medicines have been used as helpful sources for curing different ailments both for human and animals [1-3]. Plant medicines contain a large variety of constitutes which have important protective and medicinal therapies [4-7]. Products from plant medicines have ever been widely used in Asia and Africa [3,7].

In Asia and Africa, almost all the population depend on traditional health doctors, thereby medicinal plants are used to meet health needs [1,3,7]. Modern medicines exist alongside with traditional herbal medicines still keep up their reputation for the cultural and historical reasons. Herbal products are widely accessible commercially, particularly in developed countries. In developed countries, the herbal medicines are greatly used to cure different ailments $[7,8]$. The assessment of different herbal products based on their uses and therapeutic value lead to the detection of novel medicines for curing various diseases.

M. officinalis is one kind of subtropical and tropical plants, which widely distribute in subtropical and tropical districts of Asia $[9,10]$. The root of this plant is well known as "Bajitian" in China, which has been used for curing various diseases in clinical.

This review briefly describes the botanical description, plant taxonomy, history of medicinal development and the progress of the components and biological activities of $M$. officinalis to provide a reference for the researchers.

\section{Distribution and botanical description}

M. officinalis mainly found in the upland tropical and subtropical forests of Asia. In China, it is widely distributed in south districts such as Fujian, Guangdong, Guangxi, Hainan, etc. [11]. Its branches covered with a small leaf-like appendage. Root succulent hypertrophy, irregular, cylindrical, and intermittent swelling with a rosary. The young M. officinalis plant is with stiff, slender bristles and covered with fine soft hairs; it gradually becomes hairless with rough surface and the branches covered with a small leaf-like appendage at maturity. $M$. officinalis flowers are arranged in fascicules and in umbels, and thickly hairy change to slender bristles showing its ageing stage; the flower is merged for half receptacle; the calyx is pubescent to smooth; the corolla is white, bell-shaped or urn inside, and hairy, finely hirsute outside; the aggregate fruits is orbicular to flatten; and the fruits are fully fused, red and subglobose [12].

\section{Plant taxonomy}

M. officinalis is one of the most well-known and studied species of Rubiaceae (coffee family), M. officinalis is as well recognized as Gynochthodes officinalis (F. C. How) [13] or Morinda officinalisvar. hirsuta F. C. How [14] in the book of "World Checklist". M. officinalis is commonly known as "Bajitian" by Chinese [15].

Razafimandimbison et al. [16] recently demonstrated the paraphyly of the type genus Morinda with respect to its closely related species Coelospermum Blume, Gynochthodes Blume, Pogonolobus F. Muell., Sarcopygme Setch. and Christoph. As a consequence, new generic limits of Morindeae were proposed in order to make $M$. monophyletic, and that morphologically well-defined genera were recognized in Morindeae.

${ }^{*}$ Correspondence to: Jianping Yong, Xiamen Institute of Rare-earth Materials, Haixi Institute, Chinese Academy of Sciences, Xiamen, 361021, China, Tel: +86591-631-731-62; E-mail: jpyong@fjirsm.ac.cn

Canzhong Lu, Fujian Institute of Research on the Structure of Matter, Haixi Institute, Chinese Academy of Sciences, Fuzhou, 350002, China, Tel: +86-59183705794; E-mail: czlu@fjirsm.ac.cn

Key words: Morinda officinalis How, chemical components, biological activities

Received: September 25, 2018; Accepted: October 10, 2018; Published: October 15,2018 


\section{History of medicinal development}

The dried root of M. officinalis is a renowned traditional Chinese medicine and was listed in the Chinese Pharmacopoeia [15]. The roots have been used dated back to the late Qing Dynasty, Qingyuan, Sankeng and Luoding of Guangdong province, considered as one of the most important medicinal herbs (According to "Yaowu Chuchanbian" book, before Qing Dynasty medicinal materials used was Damnacanthus officinarum Huang (Rubiaceae) and Schisandra propinqua (Wall.) Hook.f. et Thoms. var. sinensis Oliv (Magnoliaceae).

M. officinalis can also be named locally as Jichang feng, Tuzi chang, Tuer chang, Heiteng zhuan, Maochang jin, and Jiyan teng. Root of $M$. officinalis is sharp, sweet and non-toxic, which can diffuse directly to the liver and kidney regions. This plant is well known to be medicinal to internal organs, such as the heart, the liver and the kidney, with other beneficial effects to man's health by nourishing kidney, strengthening bones, muscles and improving the circulation blood. M. officinalis root is extensively used in traditional Chinese medicine for curing diseases associated with kidney-yang deficiency: including fatigue, declining libido, premature ejaculation, male impotence, female infertility, rheumatism, muscular and skeletal atrophy and depression. The root of this plant has been accepted by the Health and Family Planning Commission of China for curing different ailments and can also be combined with other herbals to increase its treatment scopes.

Almost all parts of M. officinalis have been supported and approved by the Health and Family Planning Commission of China for treating different diseases in clinical, which include poor digestion, respiratory problems, immune deficiencies and high blood pressure in China since ancient times [15,17-22].

In traditional medicine, different herbs are combined together to improve their therapeutic effects because of their synergism [23]. M. officinalis is combined with Epimedium brevicomum Maxim, Ligustrum lucidum Ait., Schisandra chinensis Baill., Cuscuta chinensis Lam., Astragalus membranaceus Bge and Psoralea corylifolia to prepare a remedy for treating cancer, depression, fatigue, inflammation, osteoporosis, memory problems, high blood glucose, or kidney disease in clinical [18,24-29].

\section{Biological activities}

The M. officinalis exhibited a wide spectrum of biological activities: such as anti-inflammatory, antioxidant, antidepressant, anti-fatigue, anti-ageing, renoprotective, fertility improvement, cardiovascular protection, hypoglycemic and hyperglycemic activities, antiosteoporosis, antinociceptive, antimutagenic, antimicrobial, antihepatotoxic and anti-HIV [25,30-31].

\section{Anti-inflammatory activity}

The root of M. officinalis was reported to contain monotropeins, which exhibited higher anti-inflammatory and antinociceptive activities. It has been reported that the monotropein isolated from the root of $M$. officinalis can lengthen the action time, decrease stretching episodes, writhing antinociceptive assays and significantly diseased acute paw edema at the dosage of 20 and $30 \mathrm{mg} / \mathrm{kg}$ [25]. The literature also reported that the methanol extraction of $M$. officinalis root possess the antinociceptive and anti-inflammatory effects in-vitro and in-vivo by restraining inducible Nitric Oxide Synthase (iNOS), Cyclo-oxygenase (COX-2) and Tumour Necrosis factor- alpha (TNF- $\alpha$ ) expression by down-regulating the NF- $\kappa \mathrm{B}$ (Nuclear factor kappa-lightchain- enhancer of activated B cell) [26].The evidence also suggested that the Monotropein isolated from the roots of $M$. officinalis can decrease the ailment activity index; it also exhibited antimicrobial activity and inflammation by restraining NF- $\kappa B$ activation in colon mucosa [32]. Monotropein effectively inhibited mRNA expression of Cyclo-oxygenase (COX-2), Nitric Oxide Synthase (iNOS), Tumour Necrosis factor- alpha (TNF- $\alpha$ ) and IL-1 $\beta$ in LPS-induced RAW 264.7 macrophages [33]. Liang et al. reported that the extractions of $M$. officinalis root can affect the chronic colitis and $\mathrm{T}$ lymphocytes in mice model by reducing the symptoms of ulcerative colitis and decreasing inflammatory cytokine levels [34].

\section{Antioxidant activities}

Gao reported that the polysaccharides from $M$. officinalis can reduce the Malondialdehyde (MDA) levels in liver of mice at every dosage. The result showed that he MDA levels were significantly lower in every dosage groups than those in the control and Superoxide Dismutase (SOD), Glutathione Peroxidase (GSH-Px). While the reduced Glutathione (GSH) activities were significantly higher in every dosage groups than those in control groups [35].

Similarly, aqueous extracts of $M$. officinalis can also enhance the activity of superoxide dismutase (SOD) and glutathione peroxidase (GSH-Px), which decrease the amount of Malondialdehyde (MDA) in the muscle tissue, liver tissue and blood of the forced swimming test mice [36]. The aqueous extracts of $M$. officinalis can enhanced the activity of Superoxide Dismutase (SOD) and Glutathione Peroxidase (GSH-Px), Calcium ATPase (PMCA) and Na+/K+-ATPase of the major muscles of the forced swimming test mice, and enhanced the antioxidant activity of major muscles in the rats [37].

Mengyong et al. [38] reported that the polysaccharides from $M$. officinalis can increase the antioxidant enzyme activities and decrease in MDA levels of the testing rats. Acidic polysaccharides of $M$. officinalis possessed excellent free radical scavenging activity, which was suggested to be helpful to exhaustive exercise-induced oxidative stress [39].

Soon and Tan reported that extract of M. officinalis decreased the fasting blood glucose, hepatic and renal Thiobarbituric Acid Reactive Substances (TBARS) level and significantly improved the hepatic Superoxide Dismutase (SOD), Catalase (CAT) activities as well as Glutathione (GSH) levels in streptozotocin-induced diabetic rats [40].

It reported that $M$. officinalis can scavenge the superoxide anion and hydroxyl radicals in the chemiluminescence reaction of luminal$\mathrm{H}_{2} \mathrm{O}_{2}-\mathrm{CuSO}_{4}$ system [41]. The extract of M. officinalis was also found to scavenge the 2,2-dipicrylhydrazyl radicalin $\mathrm{TM}_{3}$ cells, which showed no effect on cytotoxicity [27].

\section{Antidepressant activity}

It has reported that $M$. officinalis root possessed anti-anxiety and antidepressant properties [18,40]. Cui et al. [42] also reported that some compounds from the roots of Morinda officinalis How $M$. officinalis possess antidepressant activity. Li et al. [43] reported that Inulin-type Hexasaccharide (IHS) can protect the PC12 cell lines at the concentrations of $0.625,1.25 \mu \mathrm{M}$ from the lesion-inducedCorticostrone, while desipramine can protect the PC12 cell lines at the concentrations of $0.25,1 \mu \mathrm{M}$. Qiu et al. reported that the aqueous extract of $M$. officinalis possess antidepressant activity. The result showed 
that the aqueous extract of $M$. officinalis can significantly improve reinforcement rate in the schedule of reinforcement at 72-seconds in mice and a significant decrease in the period of immobility. But this extract did not show good effect on spontaneous motor activity [44]. It was also reported that the aqueous extracts $M$. officinalis can improve the period of swimming loaded mice and regulate the level of monoamine neurotransmitters and reduce the level of 5-Hydroxytrytophan in the tissue of brain by balancing 'the levels of noradrenaline, dopamine and epinephrine in brain [10].

It was also reported that the ethanol extract of $M$. officinalis possess antidepressant property in the mice and rats in forced swimming test model, while the aqueous extract exhibited antidepressant activity in male mice in forced swimming test model [45-46].

\section{Anti-fatigue activity}

Polysaccharides of M. officinalis were found to possessed antifatigue activity, when tested in loaded swimming model mice at 50, 100 and $200 \mathrm{mg} / \mathrm{kg}$ dosage, which decreased levels of the blood urea nitrogen, amount lactic acid in the blood, and improved the level of glycogen stored in the liver [47]. It was also reported that the extract of M. officinalis can enhance the anti-fatigue activity [36].

\section{Anti-ageing Activity}

$\mathrm{Li}$ et al. [48] reported some compounds (such as rubiadin1-methylether, isofraxidin, scopoletin, 2-hydroxy-1-methoxy anthraquinone, and anthraquinone-2-aldehyde) isolated from $M$. officinalis showed anti-ageing activity. Other compounds (digiferruginol, 1-hydroxy-6-hydroxymethylanthraquinone, 3-hydroxy-1,2dimethoxyanthraquinone, 1,2-dihydroxy-3-methylanthraquinone and 2 -carbomethoxyanthraquinone) isolated from $M$. officinalis were also showed anti-ageing activity [49]. Ethanol extract of $M$. officinaliss was reported to improve the invulnerable ability of old rats by damaging the thymus gland index, spleen index, T lymphocyte stimulation index, B lymphocyte stimulation index, level of IL-2, the number of positive CD $28+$ cells in D-galactose [50].

\section{Renoprotective activity}

The extract of M. officinalis improved hydrocortisone-inducedKDS-Yang in rats through increasing the interruption of energy and amino acid metabolism and enhancing transmethylation. But it could not modulate the gut microbiota [51]. Some processed products of M. officinalis, including $M$. officinalis extract, liquorice-processed $M$. officinalis, salt-steamed M. officinalis and Mornda pulp could also improve the symptoms of KDS-Yang in mice, and the active sequence is: salt-steamed M. officinalis was the most significant improvement on KDS-Yang, next with liquorice-processed $M$. officinalis, Mornda pulp and M. officinalis extract [52].

\section{Fertility improvement activity}

Oligosaccharides of $M$. officinalis was used to cure impotency by shielding the DNA of sperm cells from being injured by $\mathrm{H}_{2} \mathrm{O}_{2}$ [53]. Aqueous extracts of M. officinalis improved the thickness of the epithelium of the tubule, seminiferous tubules with active sperm cells and level of testosterone in the blood, which showed little or no change with levels of follicle-stimulating hormone in the blood and lutropin in rats treated with cyclophosphane. These results indicated that $M$. officinalis can be beneficial to reproductive organs: which could help in production of matured and active sperm cells and improve secretion of gonad hormones of Leydig cell in cyclophosphamide-inducedtesticular spermatogenic disorder [27].

\section{Cardiovascular protective activity}

The oligosaccharides isolated from M. officinalis could protect the cardiac muscle against IRI rats through inhibition of oxidative stress reaction and lipidperoxidation at the dosage of 1.4 and $2.8 \mathrm{~g} / \mathrm{Kg} / \mathrm{day}$ [54]. The ethanol extract of $M$. officinalis root could eliminate the blood stasis and inhibited the rate clumping together platelets in the blood and improve haemorheological indexes and flowing of blood at the dose of 3, 6, $12 \mathrm{~g} / \mathrm{Kg}$ bw/day for days [55]. The aqueous extracts of $M$. officinalis together with vitamin $\mathrm{C}$ could reduce the serum urea nitrogen and creatinine, alleviate the superoxide dismutase and decrease the content of malondialdehyde of the swimming rats. Which indicated that $M$. officinalis combined vitamin $C$ showed a shielding effect on exerciseinduced renal injury in testing rats [56].

\section{Hypoglycemic and hyperglycemic activities}

Reports showed that M. officinalis dried roots owned both hypoglycemic and hyperglycemic properties [40]. Ethanolic extract of $M$. officinalis root decreased the immoderate blood glucose level of streptozotocin-induced- diabetic rats at $150 \mathrm{mg} / \mathrm{Kg}$, but those of normal rats increased at $600 \mathrm{mg} / \mathrm{Kg}$. n-butanol extract effectively improved the immoderate blood glucose levels of the diabetic rats at a dose $50 \mathrm{mg} / \mathrm{Kg}$ only within three hours after treatment.

\section{Chemical components}

M. officinalis contains various bioactive constituents which show therapeutic effects that can be responsible its pharmacological activity for different ailments. The compounds isolated from $M$. officinalis are: glycosides, anthraquinones, polysaccharides, mono and oligosaccharides, carboxylic acids and their derivatives and volatile oils $[11,18,20,25]$.

\section{Glycosides}

Iridoid glycosides are one of major bioactive compounds of $M$. officinalis root. Seven major active iridoid glycosides have been isolated and identified from the ethanolic extracts of M. officinalis root, the isolated compounds named as, monotropein (1), deacetylasperulosidic acid (2), asperuloside (3), asperuloside tetraacetate (4), asperulosidic acid (5) and morofficinaloside (6) [57]. Monotropein has the highest proportion among other Iridoid glycosides with approximation of $2.0 \%$. Iridoid glycosides in $M$. officinalis were further identified as deacetylasperulosidic acid and monotropein by LC/MS/MS method [58] (Figure 1).

\section{Sugar and polysaccharides}

Polysaccharides are main bioactive components of M. officinalis which are water-soluble and exist mainly in water extracts of $M$. officinalis [33]. The polysaccharides in $M$. officinalis have total weight of $10.55-35 \%$ at different locations in China [56,59]. Deng et al. [60] isolated some oligosaccharides (kestose 7 , sucrose 8 , kestose 9) from M. officinalis and confirmed their structures. Other oligosaccharides [1-kestose, nystose, hexasaccharide (10), and heptasaccharide (11)] were also isolated from M. officinalis [42-43,61-64]. Inulooligosaccharides $(18,=1 \sim 3)$ consisting of only fructosyl residues formed by $(2 \rightarrow 1)$-linkages have been found in the root $M$. officinalis [62]. Seven inulin-type oligosaccharides (DP = 3-9) in M. officinalis were analyzed qualitatively and quantitatively using a double-development HPTLC method [65] (Figure 2). 

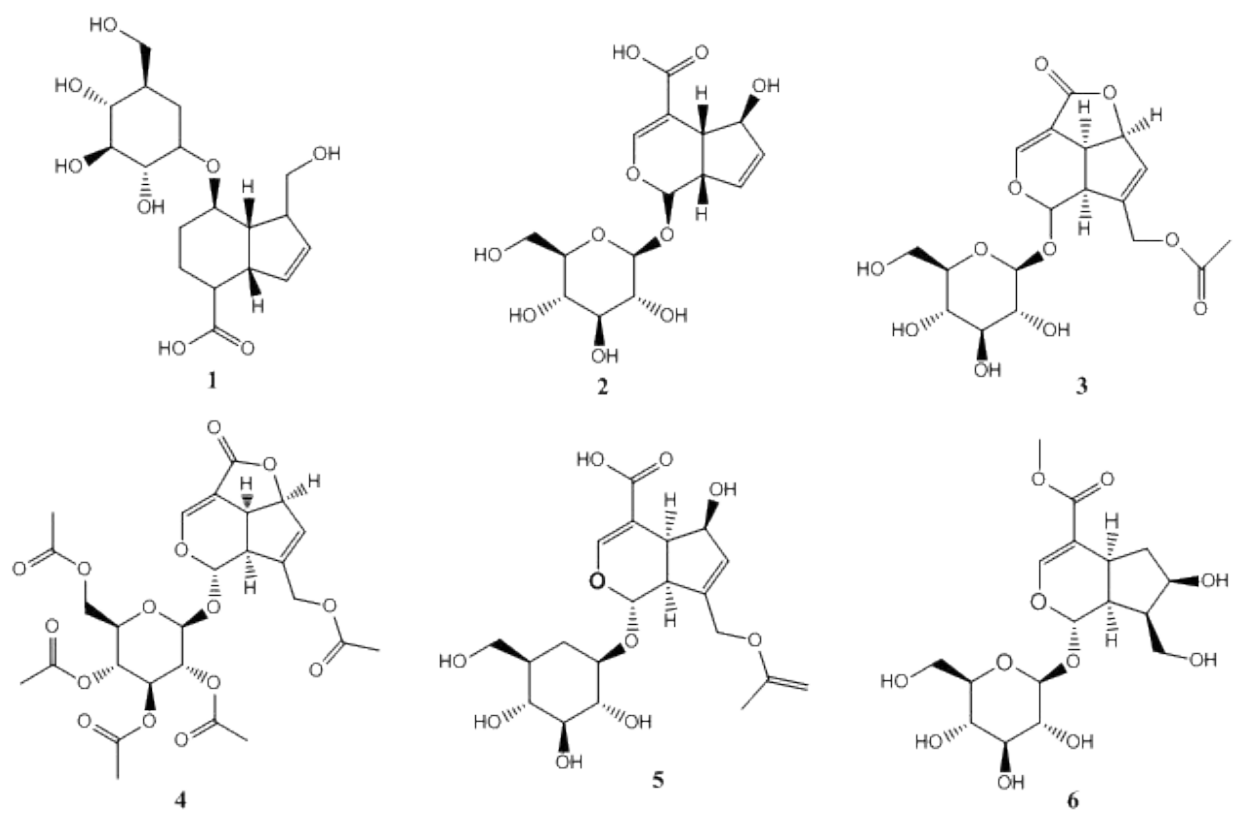

Figure 1. Iridoid glycosides. 1: Monotropein, 2: Deacetylasperulosidic acid, 3: Asperuloside, 4: Asperulosidetetraacetate, 5: Asperulosidic acid (5) and 6: Morofficinaloside<smiles>OC[C@H]1O[C@](CO)(C[C@H]2O[C@H](CO)[C@H](O)[C@@H]2O)[C@H](O)[C@@H]1O</smiles>

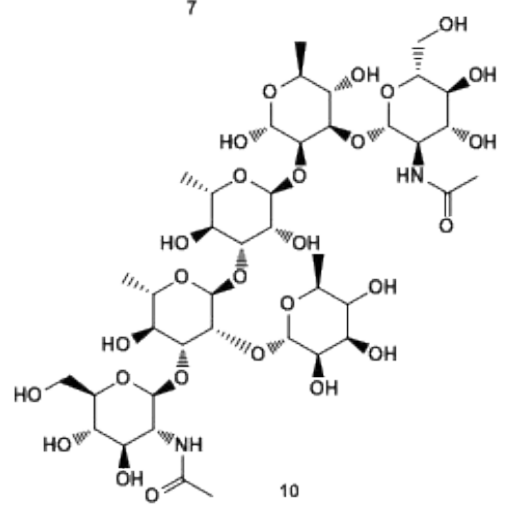

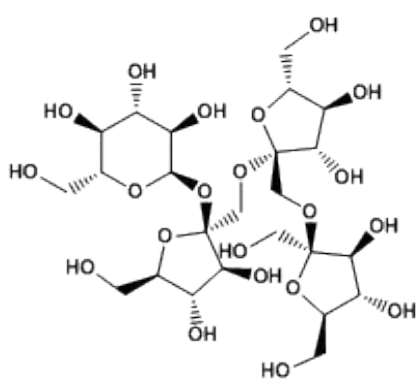

8<smiles>OC[C@H]1O[C@@](CO)(O[C@]2(O)O[C@H](CO)[C@@H](O)[C@H]2O)[C@H](O)[C@@H]1O</smiles><smiles>OC1CC(OC2CCC(OCC3OC(COC4OCC(O)(O)C(O)C4O)C(OC4OC(COC5OCC(O)C(O)C5O)C(O)C(O)C4O)C(O)C3O)OC2O)OC(COC2C(O)C(O)C(O)C(O)C2O)C1O</smiles>

Figure 2. Sugar and polysaccharides. 7: kestose, 8: Sucrose, 9: kestose, 10: 1-kestose, nystose, hexasaccharide, 11: Heptasaccharide

\section{Anthraquinones}

The Rubiaceae family is rich in anthraquinones which are everpresent in the Morinda genus (in Morinda citrifolia [66], M. elliptica [67], M. lucida [68], M. angustifolia [69] and M. Pandurifolia [70]).

Eight anthraquinones were isolated from chloroform extract of the root of $M$. officinalis, they include rubiadin (12), 1-hydroxyanthraquinone(13), rubiadin-1-methylether(14), 1-hydroxy2-methylanthraquinone (15), 1,6-dihydroxy-2-methoxyanthraquinone (16), 1,6-dihydroxy-2,4-dimethoxyanthraquinone (17), physcion
(18) and 1-hydroxy-2-methoxyanthraquinone (19). However,1,6dihydroxy-2-methoxyanthraquinone and 1,6-dihydroxy-2,4dimethoxyanthraquinone were newly discovered in this plant [71], while1-hydroxyanthraquinone has been discovered from the roots of M. officinalis, Rubia cordifolia, Damnacanthus indicus, Tabebuia avellanedae and Cassia occidentalis [72-76].

Yang et al. [77] isolated anthragallol-1,3-dimethylether (20) and 1,4-dihydroxyanthraquinone (21) with other anthraquinones, including physicion, 2-hydroxymethyl-3-hydroxyanthraquinone (22), 1,3,8-trihydroxy-2-methoxy-anthraquinone 
2-methoxyanthraquinone (24) and scopoletin from theethanolic extract of the $M$. officinalis roots. All of the isolated bioactive compounds restrained bone resorption and osteoclast TRAP activity, and 1,3,8-trihydroxy-2-methoxy-anthraquinone and physicion showed stronger inhibitory effects than other isolated bioactive compounds [78]. Lui et al. [79] reportedalizarin-2-methyl ether (25) and 1,2-dimethoxyanthraquinone [26].

Five other anthraquinones including digiferruginol (27), anthraquinone-2-carboxylic acid (28), 1,2-dimethoxy-3-hydroxy- anthraquinone (29) and lucidin-w-ethyl ether (30) [9]. 2-hydroxy3-hydroxymethyl-anthraquinone (31), rubiadin-1-methyl ether, rubiadin and 2-hydroxy-1-methoxy-anthraquinone (32)] were isolated from $M$. officinalis [80]. Yong et al. isolated physcion, 1-Hydroxy-2-methylanthraquinone, 2-Hydroxy-1methoxyanthraquinone (33), rubiadin and rubiadin-1-methyl ether. While 2-Hydroxy-1-methoxyanthraquinone was newly discovered in this plant [81]. The structures of anthraquinones were listed below (Figure 3).<smiles>[R]c1c([R])c([R])c2c(c1[R])C(=O)c1c([R])c([R])c([R])c([R])c1C2=O</smiles>

12: $\mathbf{R}_{1}=\mathrm{OH}, \mathbf{R}_{2}=\mathrm{CH}_{3}, \mathbf{R}_{3}=\mathrm{OH}, \mathbf{R}_{4}=\mathrm{H}, \mathbf{R}_{5}=\mathrm{H}, \mathbf{R}_{6}=\mathrm{H}, \mathbf{R}_{7}=\mathrm{H}, \mathbf{R}_{8}=\mathrm{H}$

13: $R_{1}=\mathrm{OH}, \mathbf{R}_{2}=\mathrm{H}, \mathbf{R}_{\mathbf{3}}=\mathrm{H}, \mathbf{R}_{\mathbf{4}}=\mathrm{H}, \mathbf{R}_{\mathbf{5}}=\mathrm{H}, \mathbf{R}_{6}=\mathrm{H}, \mathbf{R}_{\mathbf{7}}=\mathrm{H}, \mathbf{R}_{\mathbf{8}}=\mathrm{H}$

14: $R_{1}=O_{C H}, R_{2}=C_{3}, R_{3}=O C H_{3}, R_{4}=H, R_{5}=H, R_{6}=H, R_{7}=H, R_{8}=H$

15: $R_{1}=\mathrm{OH}, \mathrm{R}_{2}=\mathrm{CH}_{3}, \mathrm{R}_{3}=\mathrm{H}, \mathrm{R}_{\mathbf{4}}=\mathrm{H}, \mathrm{R}_{5}=\mathrm{H}, \mathrm{R}_{6}=\mathrm{H}, \mathrm{R}_{7}=\mathrm{H}, \mathrm{R}_{8}=\mathrm{H}$

16: $\mathbf{R}_{1}=\mathrm{OH}, \mathbf{R}_{2}=\mathrm{OCH}_{3}, \mathbf{R}_{3}=\mathrm{H}, \mathbf{R}_{\mathbf{4}}=\mathrm{H}, \mathbf{R}_{5}=\mathrm{H}, \mathbf{R}_{6}=\mathrm{OH}, \mathbf{R}_{7}=\mathrm{H}, \mathbf{R}_{8}=\mathrm{H}$

17: $R_{1}=O H, R_{2}=O C H_{3}, R_{3}=H, R_{4}=O C H_{3}, R_{5}=H, R_{6}=O H, R_{7}=H, R_{8}=H$

18: $\mathbf{R}_{1}=\mathrm{H}, \mathbf{R}_{\mathbf{2}}=\mathrm{OCH}_{3}, \mathbf{R}_{3}=\mathbf{H}, \mathbf{R}_{\mathbf{4}}=\mathrm{H}, \mathbf{R}_{5}=\mathrm{H}, \mathbf{R}_{6}=\mathrm{H}, \mathbf{R}_{7}=\mathrm{H}, \mathbf{R}_{\mathbf{8}}=\mathbf{H}$

19: $R_{1}=\mathrm{OH}, \mathbf{R}_{2}=\mathrm{OCH}_{3}, \mathbf{R}_{3}=\mathrm{H}, \mathrm{R}_{4}=\mathrm{H}, \mathrm{R}_{5}=\mathrm{H}, \mathbf{R}_{6}=\mathrm{H}, \mathbf{R}_{7}=\mathrm{H}, \mathbf{R}_{8}=\mathrm{H}$

20: $R_{1}=O_{3} H_{3}, R_{2}=O H, R_{3}=O C_{3}, R_{4}=H, R_{5}=H, R_{6}=H R_{7}=H, R_{8}=H$

21: $R_{1}=\mathrm{OH}, \mathrm{R}_{2}=\mathrm{H}, \mathrm{R}_{3}=\mathrm{H}, \mathrm{R}_{4}=\mathrm{OH}, \mathrm{R}_{5}=\mathrm{H}, \mathrm{R}_{6}=\mathrm{OH}, \mathrm{R}_{7}=\mathrm{H}, \mathrm{R}_{8}=\mathrm{H}$

22: $\mathbf{R}_{1}=\mathrm{H}, \mathrm{R}_{2}=\mathrm{CH}_{2} \mathrm{OH}, \mathrm{R}_{3}=\mathrm{OH}, \mathrm{R}_{4}=\mathrm{OCH}_{3}, \mathrm{R}_{5}=\mathrm{H}, \mathrm{R}_{6}=\mathrm{OH}, \mathrm{R}_{7}=\mathrm{H}, \mathrm{R}_{8}=\mathbf{H}$

23: $\mathbf{R}_{1}=\mathrm{OH}, \mathbf{R}_{2}=\mathrm{OCH}_{3}, \mathbf{R}_{3}=\mathrm{OH}, \mathbf{R}_{4}=\mathrm{H}, \mathbf{R}_{5}=\mathrm{H}, \mathbf{R}_{6}=\mathrm{H}, \mathbf{R}_{7}=\mathrm{H}, \mathbf{R}_{8}=\mathrm{OH}$

24: $R_{1}=H, R_{2}=O C H_{3}, R_{3}=H, R_{4}=H, R_{5}=H, R_{6}=H, R_{7}=H, R_{8}=H$

25: $\mathbf{R}_{1}=\mathrm{NC}_{7} \mathrm{H}_{7} \mathrm{SO}_{3}, \mathbf{R}_{2}=\mathrm{H}, \mathbf{R}_{3}=\mathrm{CH}_{3}, \mathbf{R}_{4}=\mathrm{OCH}_{3}, \mathbf{R}_{\mathbf{5}}=\mathrm{H}, \mathbf{R}_{\mathbf{6}}=\mathrm{OH}, \mathbf{R}_{\mathbf{7}}=\mathrm{H}, \mathbf{R}_{\mathbf{8}}=\mathrm{H}$

26: $R_{1}=O C_{3}, R_{2}=O C H_{3}, R_{3}=H, R_{4}=H, R_{5}=H, R_{6}=O H, R_{7}=H, R_{8}=H$

27: $R_{1}=\mathrm{OH}, \mathrm{R}_{2}=\mathrm{H}, \mathbf{R}_{3}=\mathrm{H}, \mathrm{R}_{\mathbf{4}}=\mathrm{H}, \mathrm{R}_{5}=\mathrm{H}, \mathrm{R}_{6}=\mathrm{H}, \mathrm{R}_{7}=\mathrm{H}, \mathrm{R}_{8}=\mathrm{H}$

28: $R_{1}=H, R_{2}=\mathrm{COOH}, R_{3}=H, R_{4}=H, R_{5}=H, R_{6}=H, R_{7}=H, R_{8}=H$

29: $R_{1}=O_{3} H_{3}, R_{2}=O C H_{3}, R_{3}=O H, R_{4}=H, R_{5}=H, R_{6}=H, R_{7}=H, R_{8}=H$

30: $\mathrm{R}_{1}=\mathrm{OH}, \mathrm{R}_{2}=\mathrm{CH}_{2} \mathrm{OCH}_{2} \mathrm{CH}_{3}, \mathrm{R}_{3}=\mathrm{OH}, \mathrm{R}_{4}=\mathrm{H}, \mathrm{R}_{5}=\mathrm{H}, \mathrm{R}_{6}=\mathrm{H}, \mathrm{R}_{7}=\mathrm{H}, \mathbf{R}_{8}=\mathrm{H}$

31: $\mathbf{R}_{1}=\mathbf{H}, \mathbf{R}_{2}=\mathrm{OH}, \mathbf{R}_{3}=\mathrm{CH}_{2} \mathrm{OH}, \mathbf{R}_{\mathbf{4}}=\mathrm{H}, \mathbf{R}_{5}=\mathbf{H}, \mathbf{R}_{6}=\mathrm{H}, \mathbf{R}_{7}=\mathbf{H}, \mathbf{R}_{8}=\mathbf{H}$

32: $\mathbf{R}_{1}=\mathrm{CH}_{2} \mathrm{OH}, \mathbf{R}_{2}=\mathrm{OH}, \mathbf{R}_{3}=\mathbf{H}, \mathbf{R}_{4}=\mathrm{H}, \mathbf{R}_{5}=\mathbf{H}, \mathbf{R}_{6}=\mathrm{H}, \mathbf{R}_{7}=\mathbf{H}, \mathbf{R}_{8}=\mathbf{H}$

33: $\mathbf{R}_{1}=\mathrm{OCH}_{3}, \mathbf{R}_{2}=\mathrm{OH}, \mathbf{R}_{3}=\mathrm{H}, \mathbf{R}_{\mathbf{4}}=\mathrm{H}, \mathbf{R}_{5}=\mathrm{H}, \mathbf{R}_{6}=\mathrm{H}, \mathbf{R}_{\mathbf{7}}=\mathrm{H}, \mathbf{R}_{\mathbf{8}}=\mathrm{H}$

Figure 3. Anthraquinones. 12: rubiadin, 13: 1-hydroxyanthraquinone, 14: rubiadin-1-methyl ether, 15: 1-hydroxy-2-methylanthraquinone, 16: 1,6-dihydroxy-2-methoxyanthraquinone, 17: 1,6-dihydroxy-2,4-dimethoxyanthraquinone, 18: physcion 19: 1-hydroxy-2-methoxyanthraquinone,

20: Anthragallol-1,3-dimethylether, 21: 1,4-dihydroxyanthraquinone, 22: 2-hydroxymethyl-3-hydroxyanthraquinone, 23: 1,3,8-trihydroxy-2-methoxy-anthraquinone, 24: 2-methoxyanthraquinone, 25: Reportedalizarin-2-methyl ether, 26: 1,2-dimethoxy-anthraquinone,

27: Digiferruginol, 28: anthraquinone-2-carboxylic acid, 29: 1,2-dimethoxy-3-hydroxy-anthraquinone, 30: lucidin-w-ethyl ether, 31: 2-hydroxy-3-hydroxymethyl-anthraquinone,

32: Rubiadin-1-methyl ether, rubiadin and 2-hydroxy-1-methoxy-anthraquinone, 33: 1-Hydroxy-2-methylanthraquinone, 2-Hydroxy-1-methoxyanthraquinone 


\section{Organic acids}

Organic acids were identified as one of the major constitutes of $M$. officinalis, hexadecanoic acid (34), linoleic acid (35) and oleic acid (36) discovered [82]. Anthraquinone-2-carboxylic acid and fumaric acid (37) were isolated from M. officinalis root [9]. Cui et al. [42] isolated succinic acid (38) as one of the identified compounds from $M$. officinalis (Figure 4).

\section{Essential oils}

According to Yong reported [83], the volatile components of $M$. officinalis oil were diisobutyl phthalate (39), borneol (40), linoleic acid, oleic acid and 3-methylbenzaldehyde. 2-methylbenzladehyde (31.97\%) (41), paeonol (11.26\%) (42), 2-methylanthraquinone (8.0\%) (43), myristaldehyde (6.53\%) (44), hexadecanoic acid (6.47\%), 1,2-benzenedicarboxylic acid (4.54\%) (45),nonanoic acid $(4.27 \%)$ (46), 8-methylundecene (2.94\%) (47), 1,3,12-nonadecatriene (2.63\%) (48), 1-allyl-4-methoxybenzene (2.42\%) (49), $\gamma$-butyrolactone $(2.74 \%)$ (50), hexanoic acid (2.42\%) (51), $\gamma$-stearolactone (2.20\%) (52) and 9,17-octadecadienal (2.09\%) (53) [84]. Thirty four constituents with $77.4 \%$ of $M$. officinalis oil have been identified, which include borneol (<29.28\%), a-curcumene (4.49\%) (54), a-zingiberene (4.88\%) (55), l-hexanol (3.4\%) (56), 2 -furanamine (3.32\%) (57), $\beta$-sesquiphellandrene (3.34\%) (58), n-nonanal (2.17\%) (59), $\beta$-bisabolene (60) and L-camphor (2.07\%) (61) [85]. Lim reported that forty-six volatile compounds were identified from fifteen years old $M$. officinalis root oil, accounted for $89.98 \%$. Nineteen compounds were reported from ten-year-old M. officinalis root oil with $70.01 \%$ [86]. Fifteen volatile components were identified from M. officinalis oil including; Hydorcarbons [n-heptadecane (62), iso-heptadecane (63), n-octadecane (64), iso-eicosane (65)], Alcohols [2,6-bis(1,1-dimethylethy1)-2-methylphenol (66)], tetradecanoic acid (67), pentadecanoic acid (68), ethylpentadecanoic acid (69), 9-hexadecenoic acid, 9-octadecenoic acid, $(Z)$ hexadecanoic acid, ethyl-hexadecanoic acid, ethyl- 9-octadecenoic acid (70) and amine ( $N$-phenyl-1-Naphthalenamine) (71) [87]. Yi et al. identified the principal compounds from the volatile oil of M. officinalis, including 3-methyl-benzaldehyde (72), pentadecanoic acid, $(Z, Z)$ 9,12-octadecadienoic acid, n-hexadeeanoic acid, oleic acid, borneol, bicyclo[4.2.0] octa-1,3,5-trien-7-O,2-methyl-9, 10-anthracenedione and benzaldehyde [88] (Figure 5).

\section{Triterpenes from M. officinalis How}

M. officinalis shown to contain Triterpenes such as stigmasterol (73), 7-hydroxy-6-methoxy-coumarin, $\beta$-sitosterol (74) and daucosterol (75) [9,89-90], scopoletin (76) [78], 3 $\beta, 5$-alkenyl-spirostol, $3 \beta, 20(\mathrm{R})$ - butyl, 5-alkenyl-cholesterol [91]. 3 $3,19 \alpha$-dihydroxyl-12-en-28-oic acid (77) identified from M. officinalis [92] (Figure 6).

Apart from the above stated compounds, morindolide [57] dimethyl-alkane, resin, ketone, Vitamin C, eleven free amino acids and seventeen amino acid hydrolysates [93-94], which add to its therapeutic properties. Various metal elements were also identified in M. officinalis, which include Potassium, Calcium and Magnessium. Iron, Manganese, Zinc and Copper [95-96].

\section{Conclusion and future perspectives}

M. officinalis is a blessing to mankind especially to the continents which favour its germination, because of its pharmacological activities. Reports showed that M. officinalis. contained Glycosides, Anthraquinones, Polysaccharides, Mono- and Oligosaccharides, organic acids as the abundant groups of compounds, which responsible for its therapeutic activities such as antioxidant, anti-inflammatory, analgesic, antiosteoporosis, antinociceptive, antidepressant, antimutagenic, antimicrobial, pro-fertility activities, antihepatotoxic and anti-HIV.

Despite the notable therapeutic activities of this plant further studies should be fully conducted on toxicity of all the extracts and isolated compounds of this plant to determine whether they can be used as medicine by animals and humans without no or little negative effects. Also, adequate studies should be on isolation and purification of bioactive compounds with sophisticated instrumentations, because there are still undiscovered bioactive compounds which also responsible for its pharmacological properties.

There should be adequate studies on dose-effects relationship, that should be prescribed to cure each ailment. Further investigations should be made on the plant therapeutic activities and their underlying mechanisms.

Functionalization of isolated compounds should be further emphasized in order to improve their activities efficacy. This can be<smiles>CCCCC(=O)O</smiles><smiles>CCC=CCC(C)CC(=O)O</smiles>

36<smiles>O=C(O)C=CC(=O)O</smiles><smiles>O=C(O)CCC(=O)O</smiles>

Figure 4. Organic acids. 34: Hexadecanoic acid, 35: Linoleic acid, 36: Oleic acid, 37: Anthraquinone-2-carboxylic acid and fumaric acid, 38: Succinic acid 
<smiles>CC(C)COC(=O)c1ccccc1C(=O)OCC(C)C</smiles>

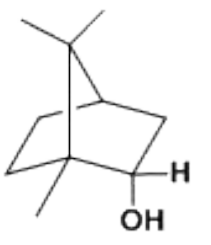

40<smiles>O=Cc1ccccc1</smiles>

41<smiles>COc1ccc(C(C)=O)c(O)c1</smiles>

42<smiles>Cc1ccc2c(c1)C(=O)c1ccccc1C2=O</smiles><smiles>CC=CC=O</smiles><smiles>O=C(O)c1ccccc1C(=O)O</smiles>

45<smiles>CCCC(=O)O</smiles>

46<smiles>C=CCCCCCC(C)CCC</smiles>

47<smiles>C=CCc1ccc(OC)cc1</smiles>

49<smiles>O=C1CCCO1</smiles>

50<smiles>CCCCCC(=O)O</smiles>

51<smiles>CC(C)=CCCC(C)(C)c1ccc(C)cc1</smiles>

54

55<smiles>CCCCC1CCC(=O)O1</smiles>

52<smiles>CCCCCCO</smiles><smiles>CC(C)=CCC=C(C)C1CC=C(C)CC1</smiles><smiles>Nc1ccco1</smiles>

57
$7_{7}^{\mathrm{CHO}}$

53<smiles>CC1(C)[C@H]2CC(=O)[C@@]1(C)C2(C)C</smiles>

61

58

62<smiles>C=C1C=CC(C(C)CCC=C(C)C)CC1</smiles>

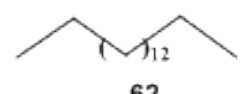<smiles>Cc1cc(C(C)(C)C)c(O)c(C(C)(C)C)c1</smiles>

66<smiles>CCCCCC(=O)O</smiles>

67

68<smiles>CCC=CCCCCCCC(CC)C(=O)O</smiles>

71

1<smiles>CCCCCCC</smiles><smiles>Cc1cccc(C=O)c1</smiles>

72

Figure 5. Essential oils. 39: Diisobutyl phthalate, 40: Borneol, 41: Linoleic acid, oleic acid and 3-methylbenzaldehyde. 2-methylbenzladehyde, 42: Paeonol(11.26\%), 43:2-methylanthraquinone, 44: Myristaldehyde, 45: Hexadecanoic acid, 1,2-benzenedicarboxylic acid, 46: Nonanoic acid, 47: 8-methylundecene, 48: 1,3,12-nonadecatriene, 49: 1-allyl-4-methoxybenzene, 50: $\gamma$-butyrolactone, 51: Hexanoic acid, 52: $\gamma$-stearolactone, 53: 9,17-octadecadienal, 54: $\alpha$-curcumene, 55: $\alpha$-zingiberene, 56: 1-hexanol, 57: 2-furanamine, 58: $\beta$-sesquiphellandrene, 59: n-nonanal, 60: $\beta$-bisabolene, 61: L-camphor, 61: L-camphor, 62: n-heptadecane, 63: iso-heptadecane, 64: n-octadecane, 65: Iso-eicosane, 66: 2,6-bis(1,1-dimethylethy1)-2-methyl-pheno1, 67: Tetradecanoic acid, 68: Pentadecanoic acid, 69: Ethylpentadecanoic acid, 70: ethyl-9-octadecenoic acid, 71: amine (N-pheny1-1-Naphthalenamine), 72: 3-methyl-benzaldehyde 
<smiles>CC[C@H](/C=C/[C@@H](C)[C@]1(C)CC[C@H]2[C@H]3CC=C4C[C@@H](O)CC[C@]4(C)[C@H]3CC[C@]21C)C(C)C</smiles>

73<smiles>[Z5]C[C@H](CC)C(C)C</smiles>

75

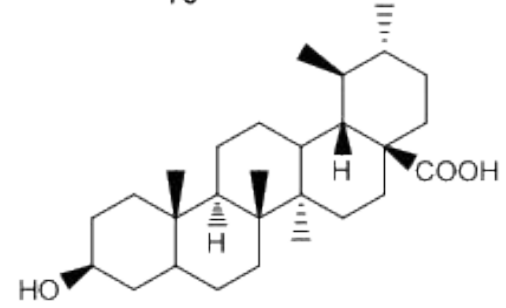

77<smiles></smiles>

74<smiles>CC1(C)[C@@H](O)CC[C@@]2(C)[C@@H]3[C@]4(C)CC[C@@]5(C(=O)O)CCC(C)(C)[C@]5(C)CC[C@@]2(C)C4=CC[C@@]3(C)[C@H]1O</smiles>

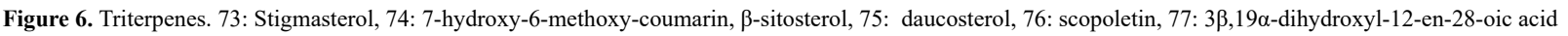

by either incorporating inorganic or organic molecules into isolated bioactive compounds or extracts.

\section{Acknowledgements}

This work was financially supported by the National Natural Science Foundation of China (21875252) and the Project of The Plan of Xiamen Science and Technology (3502ZCQ20171000).

\section{References}

1. Patwardhan B, Warude D, Pushpangadan P, Bhatt N (2005) Ayurveda and Traditional Chinese Medicine: A comparative overview. Evid Based Complement Alternat Med 2: 465-473. [Crossref]

2. Timmermans $\mathrm{K}$ (2003) Intellectual property rights and traditional medicine: policy dilemmas at the interface. Soc Sci Med 57: 745-756. [Crossref]

3. Taylor JLS, Rabe T, McGaw LJ, Jager AK, van Staden J (2001) Towards the scientific validation of traditional medicinal plants. Plant Growth Regul 34: 23-37.

4. Crozier A, Jaganath IB, Clifford MN (2009) Dietary phenolics: chemistry, bioavailability and effects on health. Nat Prod Rep 26: 1001-1043. [Crossref]

5. Dong M, He X, Liu RH (2007) Phytochemicals of black bean seed coats: isolation, structure elucidation, and their antiproliferative and antioxidative activities. $J$ Agric Food Chem 55: 6044- 6051. [Crossref]

6. Robbins RJ (2003) Phenolic acids in foods: an overview of analytical methodology. $J$ Agric Food Chem 51: 2866-2887. [Crossref]

7. Nascimento GGF, Locattelli J, Freitas PC, Silva GL (2000) Antibacterial activity of plant extracts and phytochemical on antibacterial-resistant bacteria. Braz. J. Microbiol 31: $247-256$.

8. Garima M, Pradeep S, Ramesh V, Sunil K, Saurabh SK, et al. (2011) Traditional uses, phytochemistry and pharmacological properties of Moringa oleifera plant: An overview. Der Pharmacia Lettre 3: 141-164.

9. Zhang HL, Zhang QW, Zhang XQ, Ye WC, Wang YT (2010) Chemical Constituents from the Roots of Morinda officinalis. Chin J Nat Med 8: 192-195.
10. Zhang P, Chen DL, Lin L (2014) Effects of radix Morinda officinalis decoction on contents of monoamine neurotransmitters in brain tissues of natural aging mice. $J$ Med Res 43: 79-81.

11. Zhang JH, Xin HL, Xu YM, Shen Y, He YQ, et al. (2018) Morinda officinalis How. - A comprehensive review of traditional uses, phytochemistry and pharmacology. $J$ Ethnopharmacol 213: 230-255. [Crossref]

12. Editorial Committee of Flora of China, Chinese Academy of Sciences (2015) Flora ofChina. Science Press, Beijing, 35-37.

13. Wiersema JH, León B (1999) World Economic Plants: A Standard Reference. CRC Press, Boca Raton. Retrieved as GRIN report on 17/03/2015 using query "Medizin = 'Alle Nutzungen'"

14. Razafimandimbison SG, Bremer B (2011) Nomenclatural changes and taxonomic notes in the tribe Morindeae (Rubiaceae). Muséum national d'Histoire naturelle, Paris, 33: 283-309.

15. Chinese Pharmacopoeia Editorial Board, the first division of 2005 edition, China Chemical Industry Press, Beijing, 2000, 55-56.

16. Razafimandimbison SG, Rydin C, Bremer B (2008) Evolution and trends in the Psychotrieae alliance (Rubiaceae): a rarely reported evolutionary change of manyseeded carpels from one-seeded carpels. Mol Phylogenet Evol 48: 207-223. [Crossref]

17. Zhang ZQ, Yuan L, Yang M, Luo ZP, Zhao YM (2002) The effect of Morinda officinalis How, a Chinese traditional medicinal plant, on the DRL 72-s schedule in rats and the forced swimming test in mice. Pharmacol Biochem Behav 72: 39-43. [Crossref]

18. Li YF, Gong ZH, Yang M, Zhao YM, Luo ZP (2003) Inhibition of the oligosaccharides extracted from Morinda officinalis, A Chinese traditional herbalmedicine, on the corticosterone induced apoptosis in PC12 cells. Life Sci 72: 933-942. [Crossref]

19. MengYong Z, CaiJiao W, HuSheng Z, XianWu P, JianMin F (2008) Protective effect of polysaccharides from morinda officinalis on bone loss in ovariectomized rats. Int J Biol Macromol 43: 276-278. [Crossref]

20. Li WJ, Nie SP, Yan Y, Zhu SB, Xie MY (2009) The protective effect of Ganoderma atrum polysaccharide against anoxia/reoxygenation injury in neonatal rat cardiomyocytes. Life Sci 85: 634-641. [Crossref]

21. Mateos-Aparicio I, Mateos-Peinado C, Jiménez-Escrig A, Rupérez P (2010) Multifunctional antioxidant activity of polysaccharide fractions from the soy-bean byproduct okara. Carbohydr Polym 82: 245-250. 
22. Simelane MBC, Lawal OA, Djarova TG, Opoku AR (2010) In vitro antioxidant and cytotoxic activity of Gunnera perpensa L. (Gunneraceae) from South Africa. $J$ Med Plant Res 4: 2181-2188.

23. Evans S (2008) Changing the knowledge base in Western herbal medicine. Soc Sci Med 67: 2098-2106. [Crossref]

24. Zhang ZQ, Yuan L, Yang M, Luo ZP, Zhao YM (2002) The effect of Morinda officinalis How., a Chinese traditional medicinal plant, on the DRL 72-s schedule in rats and the forced swimming test in mice. Pharmacol Biochem Behav 72: 39-43. [Crossref]

25. Choi J, Lee KT, Choi MY, Nam JH, Jung HJ, et al. (2005) Antinociceptive antiinflammatory effect of Monotropein isolated from the root of Morinda officinalis. Biol Pharm Bull 28: 1915-1918. [Crossref]

26. Kim IT, Park HJ, Nam JH, Park YM, Won JH, et al. (2005) In-vitro and in-vivo anti-inflammatory and antinociceptive effects of the methanol extract of the roots of Morinda officinalis. J Pharm Pharmacol 57, 607-615. [Crossref]

27. Chang MS, Kim WN, Yang WM, Kim HY, Oh JH, et al. (2008) Cytoprotective effects of Morinda officinalis against hydrogen peroxide-induced oxidative stress in Leydig TM3 cells. Asian J Androl 10: 667-674. [Crossref]

28. Hsieh TC, Wu JM (2008) Ethanolic extracts of herbal supplement EquiguardTM suppress growth and control gene expression in CWR22Rv1 cells representing the transition of prostate cancer from androgen dependence to hormone refractory status. Int J Oncol 32: 209-219. [Crossref]

29. Li J, Zhang HL, Wang Z, Liang YM, Jiang L, et al. (2008) [Determination content of the antidepressant extraction and analysis the trace elements from Morinda officinalis]. Zhong Yao Cai 31: 1337-1340. [Crossref]

30. Adesokan IA, Ekanola YA, Okanlawon BM (2010) Influence of cultural conditions on hydrogen peroxide production by lactic acid bacteria isolated from some Nigerian traditional fermented foods. Afr J Microbiol Res 4: 1991-1996.

31. Ali AM, Ismail NH, Mackeen MM, Yazan LS, Mohamed SM, et al. (2000) Antiviral, cyototoxic andantimicrobial activities of anthraquinones isolated from the roots of Morinda elliptica. Pharm Biol 38: 298-301. [Crossref]

32. Shin JS, Yun KJ, Chung KS, Seo KH, Park HJ, et al. (2013) Monotropein isolated from the roots of Morinda officinalis ameliorates proinflammatory mediators in RAW 264.7 macrophages and dextran sulfate sodium (DSS)-induced colitis via NF-kappaB inactivation. Food Chem Toxicol 53: 263-271. [Crossref]

33. Zhang L, Zhao X, Wang F, Lin Q, Wei W (2016) Effects of Morinda officinalis Polysaccharide on Experimental Varicocele Rats. Evidence-based Complementary and Alternative Medicine.

34. Liang J, Liang J, Hao H, Lin H, Wang P, et al. (2017) The Extracts of Morinda officinalis and Its Hairy Roots Attenuate Dextran Sodium Sulfate-Induced Chronic Ulcerative Colitis in Mice by Regulating Inflammation and Lymphocyte Apoptosis. Front Immunol 8: 905. [Crossref]

35. Gao J (2015) Polysaccharides from morinda officinalis how protect liver from oxidative stress induced by exhaustive exercise in mice. Int J Appl Res Vet Med 13: 1-6.

36. Long H, Ye WM, Mai W (2013) Effect of medicinal indianmul berry root in the treatment of postmenopausal osteoporosis. Chin Med. Phar 20: 80-81.

37. Xiao HX, Pan SL (2003) Review of the chemistry, biological activ-ity and clinical use of the plants in Genus Morinda. $J$ World Phytomed 18: 243-248. [Crossref]

38. Mengyong Z, Caijiao W, Yong G, Changsheng H, Xiao T, et al. (2009) Extraction, characterization of polysaccharides from Morinda officinalis and its antioxidan activities. Carbohydr Polym 78: 497-501.

39. Zhang H, Li J, Xia J, Lin S (2013) Antioxidant activity and physicochemical properties of an acidic polysaccharide from Morinda officinalis. Int J Biol Macromol 58: 7-12. [Crossref]

40. Soon YY, Tan BKH (2002) Evaluation of the hypoglycemic and antioxidant activities of Morinda officinalis instreptozocin- induced diabetic rats. Singapore Med J 43: 077085. [Crossref]

41. Wu ZQ, Chen DL, Lin FH, Lin L, Shuai O, et al. (2015) Effect of bajijiasu isolated from Morinda officinalis F. C. how on sexual function in male mice and its antioxidant protection of human sperm. J Ethnopharmacol 164: 283-292. [Crossref]

42. Cui C, Yang M, Yao Z, Cai B, Luo Z, et al. (1995) Studies on the Antidepressant Active Constituents in the Roots of Morinda officinalis How. Chin J Chines MateriaMedica 20: 36-63.

43. Li YF, Liu YQ, Yang M (2004) The cytoprotective effect of inulin-type hexasaccharide extracted from Morinda officinalis on PC12 cells against the lesion induced by corticosterone. Life Sci 75: 1531-1538. [Crossref]
44. Qiu ZK, Liu CH, Gao ZW, He JL, Liu X, et al. (2016) The inulin-type oligosaccharides extract from Morinda officinalis, a traditional Chinese herb, ameliorated behavioral deficits in an animal model of post-traumatic stress disorder. Metabolic brain disease. 31: 1143-1149. [Crossref]

45. Zhang ZQ, Yuan I, Zhao N, Xu YK, Yang M, et al. (2000) Antidepressant effect of the ethanolic extracts of the roots of Morinda officinalis in rats and mice. Chin Pharm J 35: 739-741.

46. Zhang ZQ, Huang SJ, Yuan I, Zhao N, Xu YK, et al. (2001) Effect of Morinda officinalis oligosaccharides on performance of the swimming test in mice and rats and the learned helplessness paradigm in rats. Chin J Pharmacol Toxicol 15: 262-265.

47. Zhang HL, Li J, Li G, Wang DM, Zhu LP, et al. (2009) Structural characterization and anti-fatigue activity of polysaccharides from the roots of Morinda officinalis. Int J Biol Micromol 44: 257-261.

48. Li YB, Wang LL, Lai XP, Feng F, Zhou YJ (2010) Active anti-aging constituents from Morinda officinalis How. Central South Pharmacy 9: 101-102.

49. Wang YL, Cui HM, Huang SJ, Li Q, Lei HM (2011) Determination of major iridoid glycosides in Morindaofficinalis from different origins or batches. Journal of Chinese Medicinal Materials 34: 1187-1190.

50. Wang FJ, Wang W, Li R, Song B, Zhang YH, et al. (2013) [Morinda officialis How extract improves microwave-induced reproductive impairment in male rats] Zhonghua Nan Ke Xue 19: 340-334. [Crossref]

51. Gong M, Ye W, Xie Y, Wang S, Liang S, et al. (2012) Metabonomic study of intervention effects of Morinda officinalis on "Kidney- yang deficiency syndrome. Zhongguo Zhong Yao ZA Zhi 37: 1682-1685. [Crossref]

52. Cui KZ, Liu YH, Zhang S, Zhang HY, Yang N (2012) Effects of drug-containing of serum Morinda officinalis Polysaccharide on the Expression of DKK-1 in Osteoblasts. Lishizhen Medicine and Materia Medica Research 23: 871-872.

53. Chen DL, Li N, Lin L, Long HM, Lin H, et al. (2014) Confocal mirco-Raman spectroscopic analysis of the antioxidant protection mechanism of the oligosaccharides extracted from Morinda officinalis on human sperm DNA. J Ethnopharmacol 153: 119124. [Crossref]

54. Wang L, Yin ZQ, Wang Y, Zhang XQ, Li YL, et al. (2010) Perisesaccharides A-E, new oligosaccharides from the root barks of Periploca sepium. Planta Med 76: 909-915. [Crossref]

55. Fu RF, Feng GQ, Yu S, Jia DH, Hu XJ, Li YJ (2007) Influences of Radix Morinda officinalis ethanolic extracts on hemorheology and platelet aggregation in blood stasis rats. J Zhengzhou Univ (Med Sci) 25: 1159-1161.

56. Guo SH, Wang HM, Huang T, Li N, Lin ZC (2006) Determination of polysaccharide from Morinda officinalis How in Nanjing. Journal of Fujian College of TCM 16: 32-33.

57. Chen H, Chen M, Huang ZZ, Lin YZ (2013) Chemical constituents of Morinda officinalis. Chinese Journal of Experimental Traditional Medical Formulae 21: 69-71.

58. Li C, Dong J, Tian J, Deng Z, Song X, (2016) LC/MS/MS determination and pharmacokinetic study of iridoid glycosides monotropein and deacetylasperulosidic acid isomers in rat plasma after oral administration of Morinda officinalis extract. Biomed Chromatogr 30: 163-168. [Crossref]

59. Cheng Z, Deng H Z, Mo QL, Li ZW (2004) Determination of the contents of valuable compositions of Morinda officinalis How in different regions and analysis of its protection for the liver. Journal of Hainan Normal University 16: 64-67.

60. Deng SD, Zhang P, Lin L, Xiao FX, Lin JR (2015) Study on intestinal absorption features of oligosaccharides in Morinda officinalis How with single-pass perfusion. Zhongguo Zhong Yao Za Zhi 40: 134-140. [Crossref]

61. Chen DL, Li N, Lin L, Long HM, Lin H, et al. (2014) Confocal mirco-Raman spectroscopic analysis of the antioxidant protection mechanism of the oligosaccharides extracted from Morinda officinalis on human sperm DNA. J Ethnopharmacol 153: 119124. [Crossref]

62. Feng F, Wang LL, Lai XP, Li YB, Cao ZM, et al. (2012) [Study on oligosaccharides from Morinda officinalis]. Zhong Yao Cai 35: 1259-1262. [Crossref]

63. Olennikov DN, Tankhaeva LM, Rokhin AV (2011) Glucofructans from Saussurea lappa roots. Chemistry of Natural Compounds 47: 339-342.

64. Li Yun-feng, Gong Zheng-hua, Yang Ming, Zhao Yi-min, LuoZhi-pu (2003) Inhibition by the oligosaccharides extracted from Morinda officinalis, a Chinese traditional herbal medicine, on the corticosterone-induced apoptosis in PC12 cells. Life Sci 72: 933-942. [Crossref] 
65. Zhou B, Chang J, Wang P, Li J, Cheng D, et al. (2014) Qualitative and quantitative analysis of seven oligosaccharides in Morinda officinalis using double-development HPTLC and scanning densitometry. Biomed Mater Eng 24: 953-960. [Crossref]

66. Ho CT, Zheng QY (2002) Quality Management of Nutraceuticals. America Chemical Society, Washington DC, 134-150. [Crossref]

67. Ismail NH, Ali AM, Aimi N, Kitajima M, Takayama H, et al. (1997) Anthraquinones from Morinda elliptica. Phytochemistry 45: 1723-1725.

68. Rath G, Ndonzao M, Hostettmann K (1995) Antifungal anthraquinones from Morinda lucida. Int J Pharmacogn 33: 107-114.

69. Xiang W, Song QS, Zhang HJ, Guo SP (2008) Antimicrobial anthraquinones from Morinda angustifolia. Fitoterapia 79: 501-504. [Crossref]

70. Ruksilp T, Sichaem J, Khumkratok S, Siripong P, Tip-pyang S (2011) Anthraquinones and an iridoid glycoside from the roots of Morindapandurifolia. Biochem Sys Ecol 39: 888-92.

71. Yang YJ, Shu HY, Min ZD (1992) [Anthraquinones isolated from Morinda officinalis and Damnacanthus indicus]. Yao Xue Xue Bao 27: 358-364. [Crossref]

72. Buckingham J (2001) Dictionary of Natural Products on CD-ROM. Boca Raton, FL, Chapman \& Hall/CRC Press.

73. Steinert J, Khalaf H, Rimpler M (1996) High-performance liquid chromatographic sepa-ration of some naturally occurring naphthoquinones and anthraquinones. $J$ Chromatogr A 723: 206-209.

74. Wang SX, Hua HM, Wu LJ, Li X, Zhu TR (1992) Anthraquinones from the roots of Rubia cordifolia L. Yaoxue Xuebao 27: 743-747.

75. Mori H, Yoshimi N, Iwata H, Mori Y, Hara A, et al. (1990) Carcinogenicity of naturally occurring 1-hydroxyanthraquinone in rats: induction of large bowel, liver and stomach neoplasms. Carcinogenesis 11: 799-802. [Crossref]

76. Brown JP, Brown RJ (1976) Mutagenesis by 9,10-anthraquinone derivatives and related compounds in Salmonella typhimurium. Mutat Res 40: 203-224. [Crossref]

77. Yang F, Su YF, Zhao ZQ, Que M, Li TX, et al. (2016) Anthraquinones and Iridoids from Morinda officinalis. Chemistry of Natural Compounds 52: 989-991.

78. Wu YB, Zheng CJ, Qin LP, Sun LN, Han T, et al. (2009) Antiosteoporotic Activity of Anthraquinones from Morinda officinalis on Osteoblasts and Osteoclasts. Molecules 14: 573-583. [Crossref]

79. Liu Q, Kim SB, Ahn JH, Hwang BY, Kim SY, et al. (2012) Anthraquinones from Morinda officinalis roots enhance adipocyte differentiation in 3T3-L1 cells. Nat Prod Res 26: 1750-1754. [Crossref]

80. Wu YB, Wu JG, Zheng CJ, Han T, Qin L P, et al. (2013) Quantitative and chemical profiles analysis of the root of Morinda officinalis based on reversed-phase high performance liquid chromatography combined with chemometrics methods. J Med Plants Res 7: 2249-2258.
81. Yong J, Lu C, Huang S, Wu X (2015) Chemical Components Isolated from the Roots of Morinda officinalis. Chem nat compd 51: 476-477.

82. Yin YT, Yang ZM, Hu J, Van S, Hong ZC, et al. (2009) Study on extraction of Volatile components from Morinda officinalis by different Methods. J Anhui Agric Sci 37: 11540-11541.

83. Yong-tao YI ((2009) Study on extraction of volatile components from Morinda officinalis How by different methods. J Anhui Agri Sci 24: 85.

84. Yang JY, Kim MG, Park JH, Hong ST, Lee HS (2014) Evaluation of benzaldehyde derivatives from Morinda officinalis as anti-mite agents with dual function as acaricide and mite indicator. Sci Rep 4: 7149. [Crossref]

85. Liu WW, Gao YQ, Liu JH, Huo X, Yang NJ (2005) Determination of chemical constituents of the volatile oil from radix Morindae officinalis. Biotechnology 15: 5961.

86. Lim TK (2016) Edible Medicinal and Non-Medicinal Plants: Volume 11 Modified Stems, Roots. Science PP: 392. [Crossref]

87. Li N, Qin LP, Han T, Wu YB, Zhang QY, et al. (2009) Inhibitory effects of morinda officinalis extract on bone loss in ovariectomized rats. Molecules 14: 2049-2061. [Crossref]

88. Yi YT, Yang ZM, Fan JQ, Hong ZC, Chen LY, et al. (2009) Study of the volatile components of radix Morindae officinalis by GC/MS. Nat Prod Res De 30: 17-20.

89. Yoshikawa M, Yanaguchi S, Nishisaka H, Yamahara J, Murakami N (1995) Chemical constituents of Chinese natural medicine, Morindae Radix, the dried roots of Morinda offi-cinalis How.: Structures of morindolide and morofficinaloside. Chem pharm Bull 43: $1462-1465$.

90. Li S, Ouyang Q, Tan X, Shi S, Yao Z (1991) [Chemical constituents of Morinda officinalis How]. Zhongguo Zhong Yao Za Zhi 16: 675-676, 703. [Crossref]

91. Li J, Zhang HL, Jiang L, Yang DP, Ma W (2010) Chemical constitution of the roots from Morinda officinalis. Journal of South-Central University for Nationalities 29: 5355 .

92. Chen MY (2009) Chemical constituents of Morinda officinalis. Yunnan Journal of Traditional Chinese Medicine and Materia Medica 15: 63-64.

93. Zheng HZ, Dong ZH (1997) Radix Morindae officinalis. In: Modern Study of Traditional Chinese Medicine, Xue Yuan Press 2: 1234-1245.

94. Li S (1990) Study of chemical ingredients of in Radix Morindae officinalis with GCMS computer integration. Proprietary Chinese Medicine 12: 33.

95. Qiao ZS, Wu H, Su ZW (1991) Comparison with the pharmacological actions of Morinda officinalis, Damnacanthus officinarum and Schisandra propinqua. Zhong Xi Yi Jie He Za Zhi 11: 415-417. [Crossref]

96. Wu YJ, Liu J, Wu YM, Liu LE, Zhang HQ (2005) [Determination of polysaccharide from Chinese medicine Morinda officinalis how and its trace elements analysis]. Guang Pu Xue Yu Guang Pu Fen Xi 25: 2076-2078. [Crossref]

Copyright: (C2018 Olatunde OZ. This is an open-access article distributed under the terms of the Creative Commons Attribution License, which permits unrestricted use, distribution, and reproduction in any medium, provided the original author and source are credited. 